\title{
Caldera of Godean, Sleman, Yogyakarta: A Volcanic Geomorphology Review
}

\author{
Hill. Gendoet Hartono*, Adjat Sudradjat, Okki Verdiansyah \\ Sekolah Tinggi Teknologi Nasional Yogyakarta \\ *Corresponding author (e-mail: hilghartono@sttnas.ac.id)
}

Received: 07 December 2016 / Accepted: 19 May 2017 / Published: 01 July 2017

\begin{abstract}
Godean Hills is located approximately $10 \mathrm{~km}$ westward from the Yogyakarta City. The landscape of Godean hills and plains is affected by various factors, such as lithology, geological structure, and sub-aerial process. The purpose of this study was to reveal the landscape of Godean. The method consisted of field study, morphological variables assessment, rock sampling, and laboratory analysis. The results of field mapping indicated that the landscape of Godean is an isolated hill with a steep slope of $>40^{\circ}$ and an elevation of $+231 \mathrm{~m}$ a.s.l, passed by the rivers flows from northeast to south-west that disembogue into the west part of Kulon Progo. The morphology of Godean hills varies including G. (Gunung/Mountain) So (+173 m a.s.l), G. Gede (+218 $\mathrm{m}$ a.s.l), G. Wungkal (+187 $\mathrm{m}$ a.s.l), G. Butak (+154 $\mathrm{m}$ a.s.l), and G. Berjo ( + 175 $\mathrm{m}$ a.s.l), dominated by the lithology of igneous rock, which is composed of porphyry andesite-micro-diorite, pumice lapilli, and quartz-rich lapilli-tuff. In addition, most of the igneous rocks have weathered and have been altered to clays, while the deposition from Merapi volcano formed a landscape with an altitude between $+100-+150 \mathrm{~m}$ a.s.1 surrounding Godean Hills. Sentolo Formation was found in Kembang, Bantul, which is located approximately $\pm 5 \mathrm{~km}$ in the south of the study area $N 93^{\circ} \mathrm{E} / 12^{\circ}$, while the distribution in the south-west and northeast relatively covers the Godean hills in curve shape. The results of the analysis provide information related to Godean landscape that it is the remains of the volcanic caldera, with various igneous rock types and volcaniclastics deposits, as well as endured the occurrences of hydrothermal alteration and mineralisation. Further geophysical research is required to determine the configuration of igneous rocks under the earth's surface.
\end{abstract}

Keywords: Genesis, geophysical, micro-diorite, landscape, caldera.

Abstrak. Daerah Godean terletak lebih kurang $10 \mathrm{~km}$ di sebelah barat kota Yogyakarta. Genesis bentang alam tinggian dan dataran daerah Godean dipengaruhi oleh berbagai faktor utama yang berbeda, seperti litologi, struktur geologi, dan proses geologi di permukaan bumi. Tujuan penulisan makalah ini adalah mengungkap keberadaan bentang alam daerah Godean. Metode pendekatan yang dilakukan adalah kunjungan lapangan, pengukuran variabel morfologi, pengambilan contoh batuan, dan analisis batuan di laboratorium. Hasil pemetaan lapangan menunjukkan bahwa daerah Godean berupa tinggian terisolir yang terdiri atas beberapa bukit dengan kelerengan terjal $\left(>40^{\circ}\right)$, ketinggian $+231 \mathrm{~m}$ dpl., dilewati sungai-sungai yang relatif berarah ke timur laut-barat daya dan bermuara di K. Progo di sebelah barat. Morfologi tinggian Godean seperti G. So (+173 m), G. Gede (+218 m), G. Wungkal (+187 m), G. Butak (+154 m) dan G. Berjo $(+175 \mathrm{~m})$ disusun oleh litologi yang sangat keras berupa batuan beku berkomposisi andesit porfiri-diorit mikro, batu lapili pumis dan batu lapili tuf yang kaya kuarsa, dan sebagian besar batuan beku telah mengalami pelapukan dan teralterasi menjadi tanah liat, sedangkan material endapan G. Merapi membentuk bentang alam dataran dengan ketinggian antara $+100-$ +150 mdpl. mengelilingi tinggian Godean. Formasi Sentolo yang tersingkap di desa Kembang,

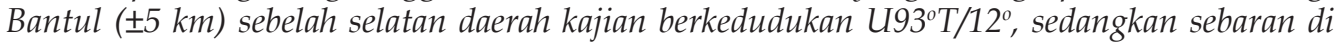
bagian barat daya dan timur laut relatif melengkung melingkupi tinggian Godean. Hasil analisis memberikan pemahaman bahwa tinggian Godean merupakan bentang alam sisa tubuh gunung api berupa kaldera atau bregada, dengan variasi litologi batuan beku, batuan vulkaniklastik 
dan kehadiran alterasi hidrotermal dan mineralisasi. Penelitian geofisika lanjut perlu dilakukan untuk mengetahui konfigurasi batuan beku bawah permukaan bumi.

Kata Kunci: Genesis, geofisika, diorit mikro, bentang alam, bregada.

\section{Introduction}

Godean is part of the Godean District, Sleman Regency, Yogyakarta (Figure 1), which is situated precisely in the southwestern of Sleman Regency and approximately $10 \mathrm{~km}$ westward from Yogyakarta City. In general, Godean is well-known for the tiles and red brick manufacture by utilising local raw material while the area is surrounded by very fertile land in the form of rice fields. Geologically, Godean Hills are an isolated area that consists of G (Gunung or Mountain). So (+173 m a.s.l), G. Siwareng (+194 m a.s.l), G. Gede $(+218 \mathrm{~m}$ a.s.l), G. Wungkal (+187 $\mathrm{m}$ a.s.l), G. Ngampon (+222 $\mathrm{m}$ a.s.l), G. Gedang (+193 m a.s.l), G. Patuk (+231 $\mathrm{m}$ a.s.l), G. Butak (+154 $\mathrm{m}$ a.s.l) and G. Berjo (+175 $\mathrm{m}$ a.s.l) surrounded by plains. Those isolated hills are constituted of intrusion igneous rocks that consist of andesite and diorite in the Old Andesite Formation, while the plains are constituted of younger volcaniclastic rocks from G. Merapi (van Bemmelen, 1949; Rahardjo et al., 1977). This formation has been studied several times for the fulfilment of Sandi Stratigrafi Indonesia and yet the understanding to reveal the genesis of the landscape of hills has not been investigated comprehensively and continuously. The genesis of a landscape involves some important aspects such as the source of material, the mechanical process of the formation, the age and environmental factors of the formation. The material sources describe the origin of intrusion rocks and volcanic rocks that made up the hills and plains of Godean including the formation process and the formation period, while the environmental aspect refers to the sub-surface or sub-aerial formation. The genesis of the formation of hills landscape and the plains surrounding the hills became the main focus of this study.]

Rahardjo et al. (1977) mentioned that geologically, Godean hills are a part of Kulonprogo Mountains. Kulonprogo Mountains are built up from the ancient volcanoes of G. Gadjah, G. Idjo, and G. Menoreh, well-known as "Oblong Dome" due to its elongated dome from northeastern to southwestern with a length of $32 \mathrm{~km}$ and a width of 15-20 km (Figure 2). Godean hills, in general, are also an igneous body building that has been deformed from weathering, alteration, intrusion, and fault. It is a high possibility that those processes formed the modern landscape.

Nanggulan Formation (Tabel 1), which member of Seputih consists of marks in upper part, then conformable deposit of intercalation volcanic and coherent lava, in addition to shallow intrusion of old Andesite Formation. Jonggrangan Formation and Sentolo Formation were overlapped and distributed upon Old Andesite Formation.

Lelono (2000) mentioned that Nanggulan Formation was formed in the Eocene Epoch, which can be concluded based on the findings of Palynomorphs that is the characteristic of lowland/rainforest and the climate indicator. In addition, Budiadi (2008) concluded that the landscape of Kulonprogo Mountain was generated from the geological structure. Hartono and Pambudi (2015) mentioned that the rocks building up Nanggulan Formation are the deposits of small basin between two hills. Meanwhile, Sipatriot (2016) concluded that Godean was a relic of ancient volcano and Bronto (1999) mentioned about industrial mineral deposit in Godean that consists of clays originated from the weathering of igneous rocks. 


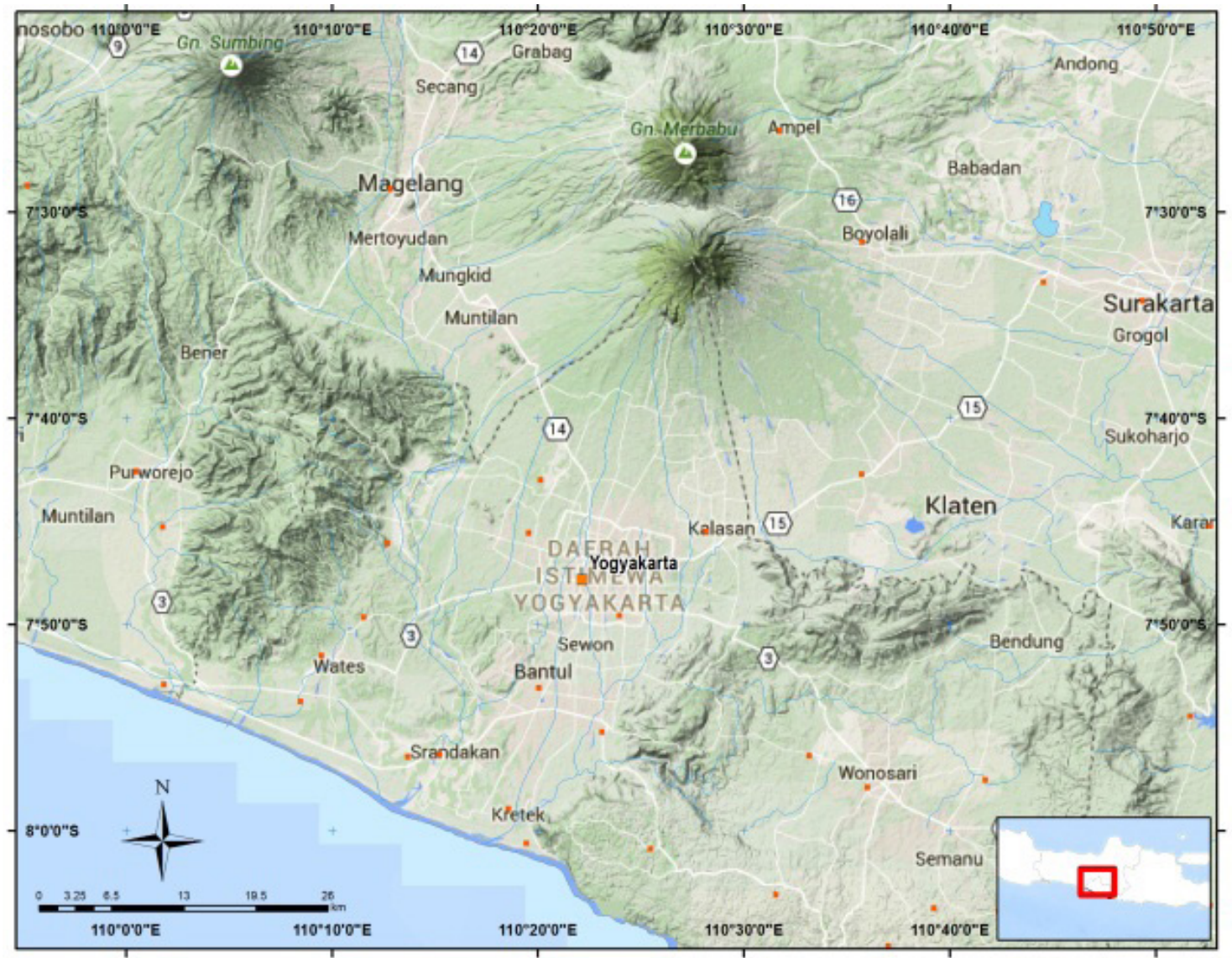

Figure 1. Red Rectangular Showing the Study Area Location.

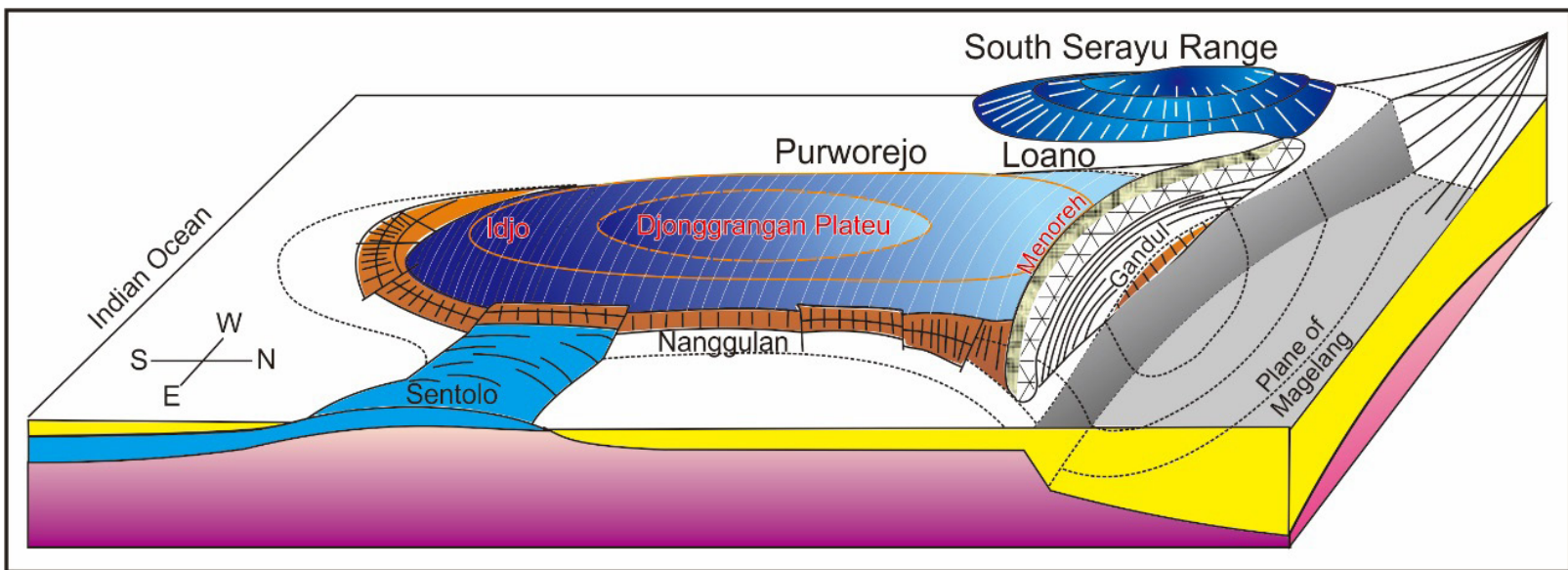

Figure 2. Oblong Dome Landscape as the Relict of Several Ancient Volcanoes such as Gadjah, Idjo, and Menoreh (van Bemmelen, 1949).

\section{Research Method}

This research is a surface geological study that included geological mapping, measurement of geomorphological aspect, geological structure, and rock sampling. Geological mapping was done based on previous studies and literatures that was specifically performed on Nanggulan hills and in addition, the measurement of geological structure elements to determine their role in the formation of the landscape of the study area, as well as the measurement of geomorphological aspect to determine the slope, height difference, pattern of flow, stadia, and the type of streams 
in the context of the landscape characteristic, of deposition, the process of formation, and and the process that accompanied it were arrived out. Furthermore, petrographic analysis was carried out to identify the basic mineral composition, texture, and structure depositional environment.

The stratigraphy of Kulonprogo Mountains is initiated by siliciclastic sediments classified as

Table 1. The Stratigraphy of Kulonprogo Based on Several Studies, and Interpretation of Volcanism and Magmatism age (in Red Background colour).

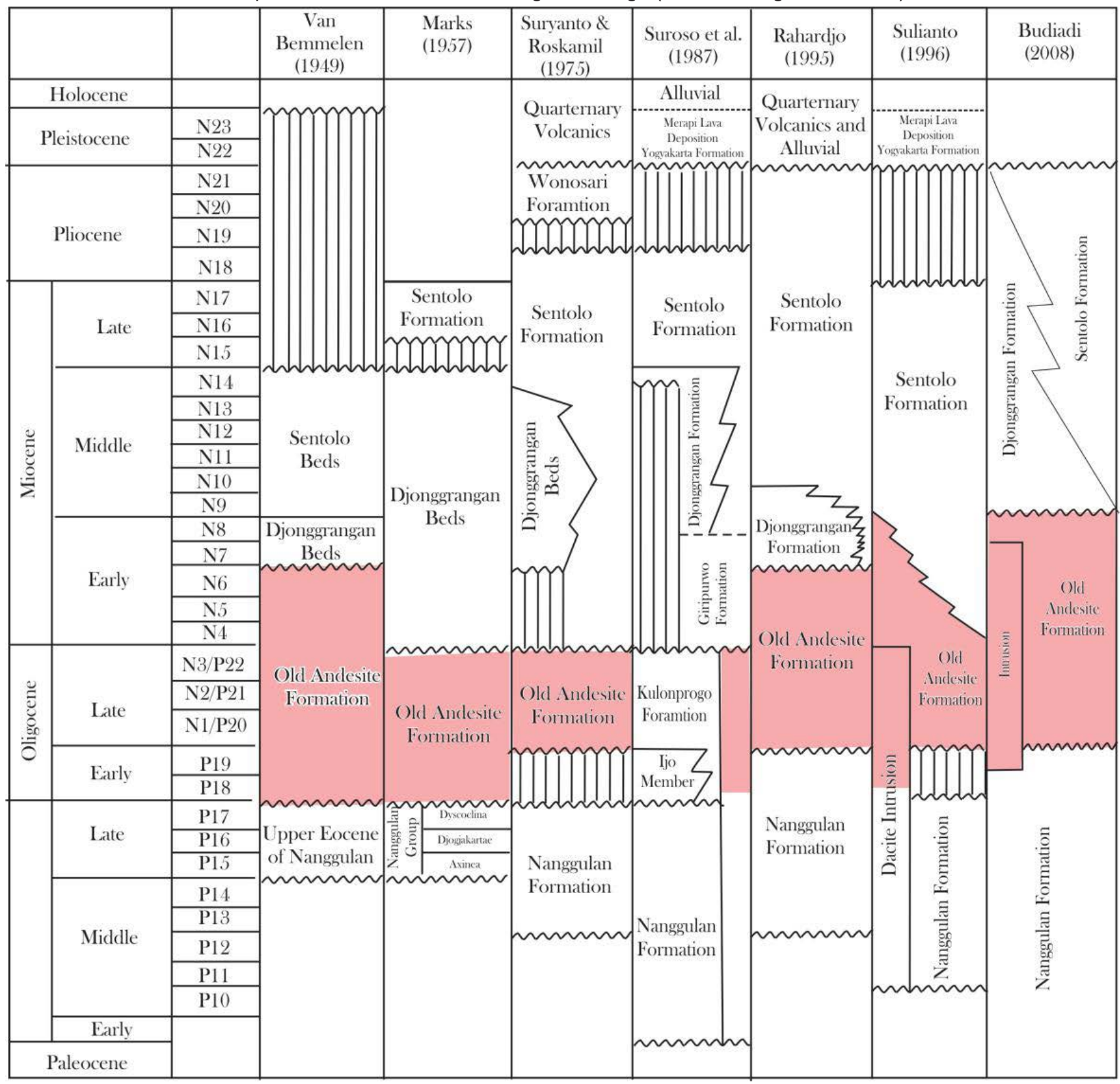

\section{Results and Discussions}

The field study showed that the rocks making up the Godean hills are composed of volcanic rocks and sub-volcanic rocks. Volcanic rocks generally contain lapilli tuff and lapilli pumice, while the sub-volcanic rocks are intrusion rock composed of basalt, andesite, dacite, and micro-diorite (Figure 3). Lapilli tuff, lapilli pumice, tuff, and others volcanic rocks are originated from eruption activity, where pumice indicates magma series composed of acid and the massive 
eruption of volcanoes. Furthermore, the intrusion rocks are generally the igneous rock composed of basalt, andesite and rare rocks including xenolith in igneous rocks composed of porphyritic andesite-dacite. It shows the volcanic activities that occur repeatedly and some rocks that are intruded enter into the intrusion rocks, as in tuff within the dacite rocks. It is important in the context of this study that this process took place in the body of magma or the magma chamber of a volcano body.

Based on the variation of the rock composition revealed in the study area, an explanation of the process of magma differentiation that leads to the behaviours of Godean volcanic eruptions is provided. Period of destructive eruption probably contributed to the formation of the volcanic landscape in Godean. The volcanic eruptions formed craters that vary in diameter $(>2 \mathrm{~km})$ and are characterized by perfect circular and semi-circular shape of crescent (half moon, horseshoe shape). On the contrary, the inside of the circular structure composed of intrusion rock, alteration rock, volcanic neck, and lava dome. The remains of the outer landscape generated from volcanic eruption activity frequently have symmetrical shape, steep rock ramps of volcanic beds, and constituted of intercalation of pyroclastic rocks and coherent lava.

The petrographic analysis showed the igneous rocks that made up the Godean hills are generally intermediate igneous rocks consisting of hornblende andesite, pyroclastic rocks, and acid rocks of dacite. It indicated the amount of quartz mineral that reaches $5 \%-30 \%$ and the pyroclastic rocks with glass texture in tuffs, pumice, while the intrusion rocks is porphytic aphanitic, with plagioclase mineral type of andesine $\left(\mathrm{An}_{44} \mathrm{Ab}_{56}\right)$ (Figure 4). Volcanic rocks consisting of coherent lava and pyroclastic made up the Godean landscape that lies in the form of circular to semicircular landscape (Figure 5), where rocks that had undergone alteration was found, while the plains that surround it constituted of volcaniclastics material produced by the volcanic activity of Mount Merapi located \pm $25 \mathrm{~km}$ to the north (Rahardjo et al., 1977).

Geomorphology can be used as basic framework to land resources evaluation with landform unit as land mapping unit or evaluation unit (Sutikno, 1990). Geomorphological analysis indicated that the landscape was built from active volcano (intrusion, melt, and eruption) where material and composition is associated with magma and lava, as well as its geological structure. Godean hills reflect the phenomenon, as demonstrated in Figure 5A where the Hill is situated inside a circular structure of $2 \mathrm{~km}$ in diameter and the distribution was covered by carbonate rock of Sentolo formation that shows the rocks layering tilt to south with the position $\mathrm{N} 92^{\circ} \mathrm{E} / 12^{\circ}$ (Figure $5 \mathrm{~B}$ ), while the distribution of the south western and northwestern north parts follows a circular structure.

The circular structure on the west side, followed by a curved shape of the Progo river is a reflection of the body architecture of ancient Godean volcano. The curving river stream might also be affected by the resistance of volcanic rocks and the structure of the fire mountain. In contrast to the eastern part, there is neither river nor curved structures such as in the west. This is because the eastern part covered by clastic material from Mount Merapi and the river flow patterns evolve over the sediment of Merapi. In the geological map (Figure 5A and 5B), the hills built up Godean separately and apparently unrelated. The explanation to this is the possibility of the faulted igneous body hence the faults become resistant and eroded, or the landscape is a dome in the surface (cryptodome), the body of an intrusion, or volcanic neck in the volcanic crater. 


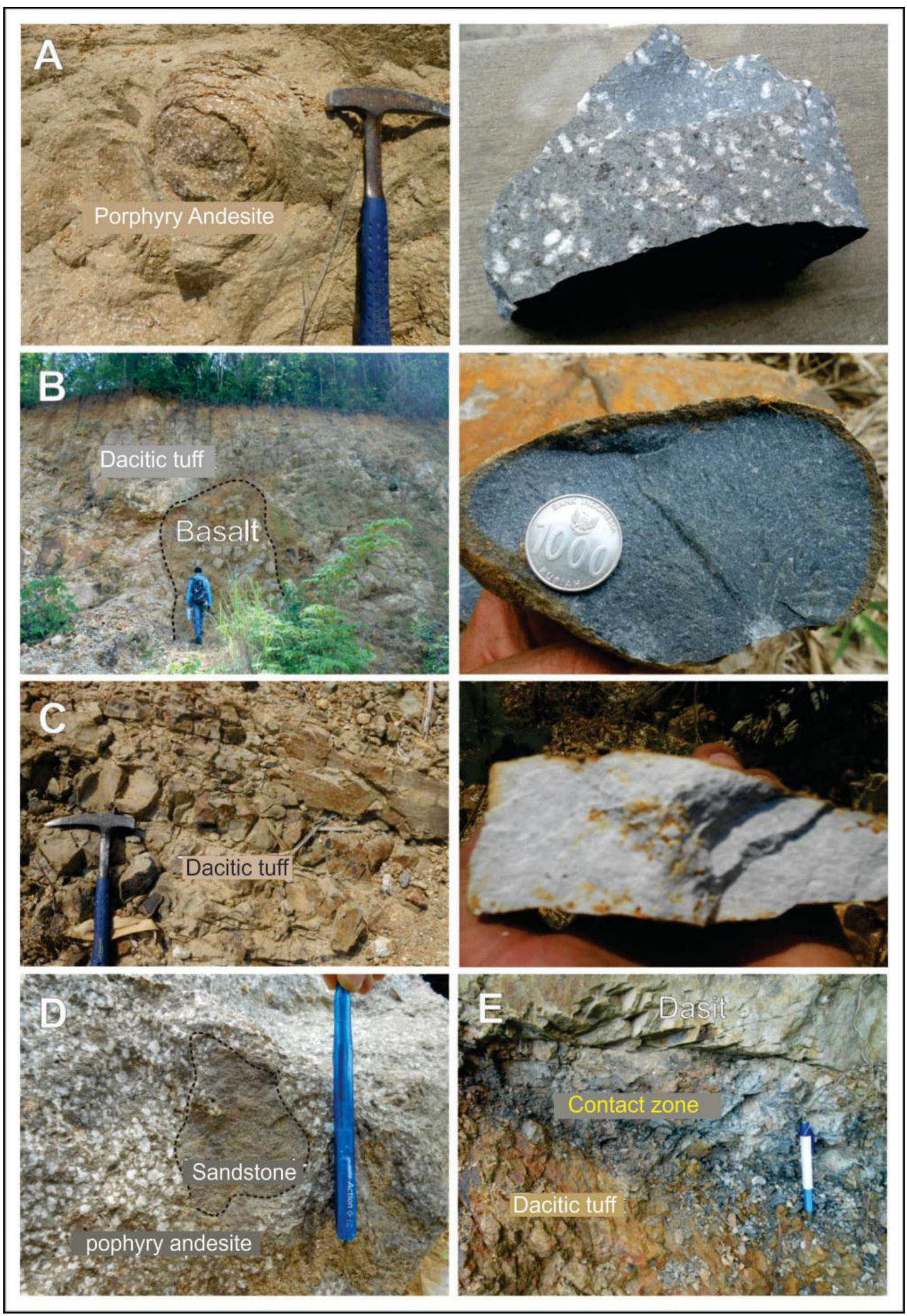

Figure 3. Various Types of Igneous Rock in Godean. (A) Spheroidal Weathering of Porphyry Andesite; (B) Intrusive Rock of Basalt; (C) Bedding of Dacitic Tuff; (D) Xenolith of Sandstone in Andesite ; (E) Contact Zone (Sill) Dacite with Dacitic Tuff. Notes: Right Side Photo Hand Specimen Sizes (A, B, and C). 

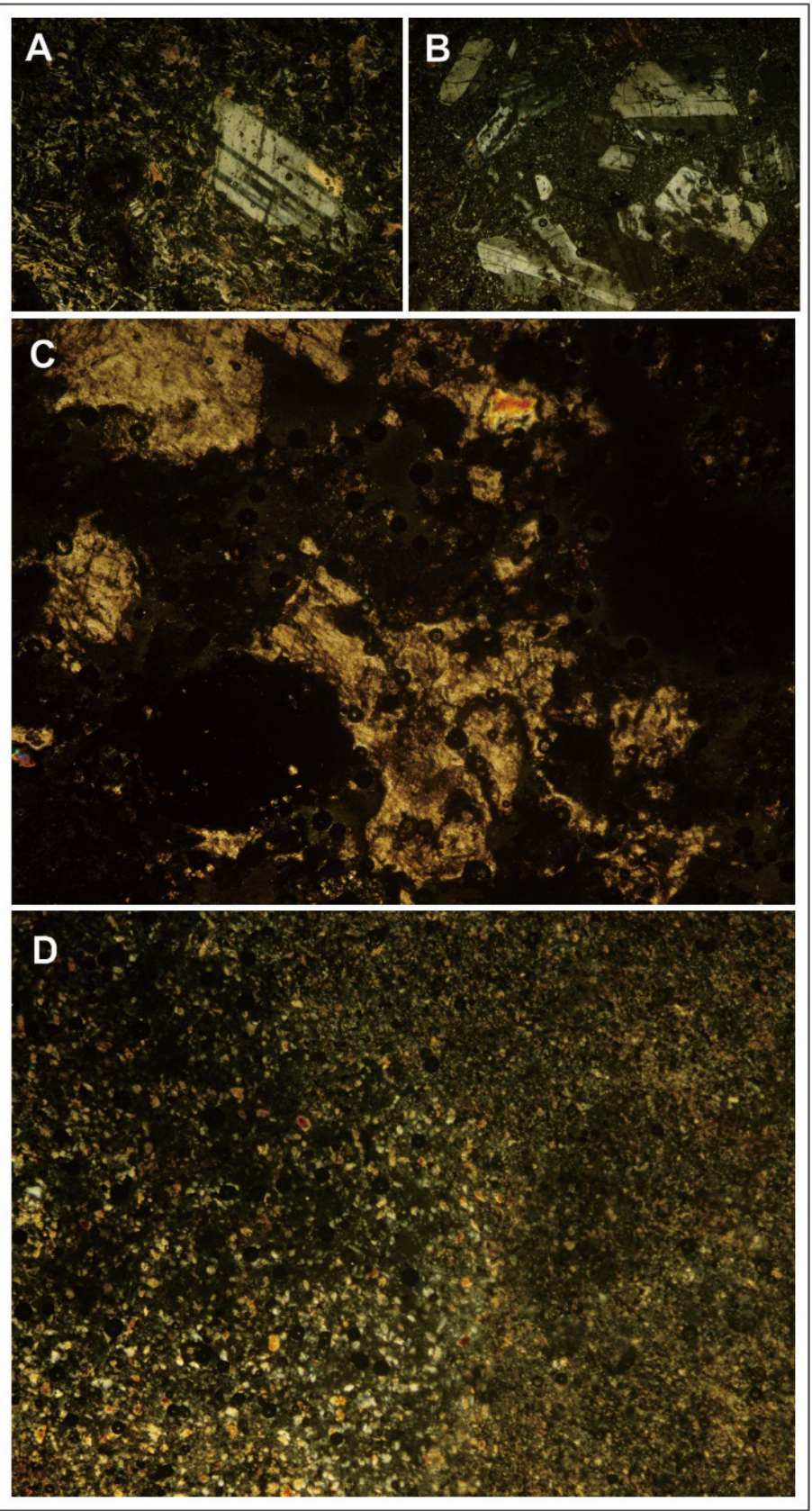

Figure 4. Photomicrograph of Volcanic Rocks that Build Up Godean Landscape, (A) Porphyritic Andesite; (B) Microdiorite; (C) Pumice; and (D) Glass Tuff.

The oldest stratigraphy of Godean is constituted of Nanggulan Formation consisting of Eocene mudstone and sandstone covered by the deposit of Old Andesite Formation composed of igneous rock, andesitic breccia and tuff. Igneous rock is in the form of lava and intrusive rock (Rahardjo et al., 1977). It confirms that Godean was built by a group of volcanic rock from eruption process activity and shallow intrusion. Nevertheless, Sutanto et al. (1994) asserted the results of absolute age dating from igneous rock shows the Old Andesite Formation aged 25.35-29.63 million years ago. It means that the volcanic activity in Godean occurred simultaneously with those in the area of Kulon Progo, or is possibly older when it is assessed from the morphology and weathering type.

In Godean, hydrothermal alteration and mineralisation occurred particularly in G. Wungkal that indicates the ancient volcanic activity, which can beassumed as thegeothermal system in ancient time. The occurrences of hydrothermal alteration (Verdiansyah, 2016) can verify the presumption of Godean as the product of volcanic process. 

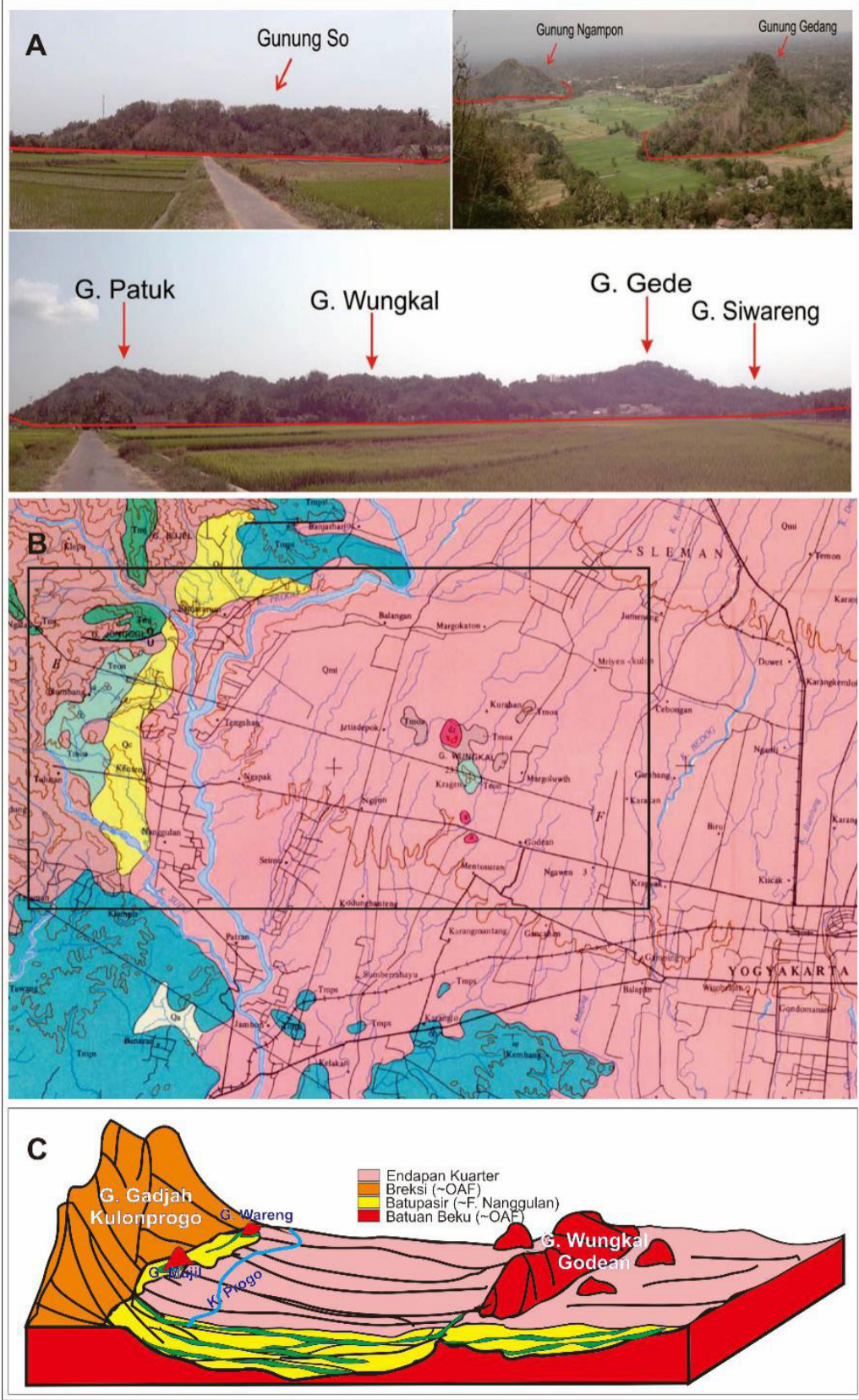

Figure 5. The Morphology and Landscape of Godean Hills is Composed of Volcanic Rock Surrounded by FluvioVolcanic Plain. (A) Morphology of Hills with Tumors Like Morphology; (B) Geological Map Shows the Distribution of Lithologies (Rahardjo et al., 1977); (C) Sketch of Godean Caldera with G. Wungkal as the Central Facies.

Figure 5C shows Godean landscape as volcanic geomorphology formed from selfdestruct process of volcanic eruption. This eruption is associated with caldera eruption type, hence, it is the remains of the caldera. Genesis of the landscape of Godean is relatively similar with G. Gajahmungkur in Wonogiri, Central Java, which is also characterized by caldera morphology (Hartono, 2010). In fact, the identification of hypothesis is also verified by the findings of pumice and dacitic tuff as the product of big explosive activity associated with acidic magma. In addition, opened circular and a half circular landform have more than 20 $\mathrm{km}$ in diameter, meanwhile there is a crater of $6 \mathrm{~km}$ in diameter. The opened structure might have endured weathered process and erosion causing only the west side can be clearly observed and measured.

The plains constituted of theclastic material from G. Merapi is predicted to be the early body of G. Godean, which occupies the proximal 
facies, medial facies, and distal facies. Further study is required to prove that Godean is an isolated volcanic cone between Kulonprogro Mountains and Southern Mountains.

Reconstruction of the lower plain of Godean has been interpreted by Pertamina (2008 in Winardi et al., 2013). The reconstruction explained that the geophysical gravity measurements illustrate that under the Godean hills, there was the rock mass of $2.49 \mathrm{~g} / \mathrm{cc}$ to a depth of $2500 \mathrm{~m}$ classified as volcanic rock aged approximately 28.5 million years ago (Figure 6). Reconstruction model of the earth's surface and subsurface implied on the basin model in volcanic arc and the discovery of new natural resource sites.

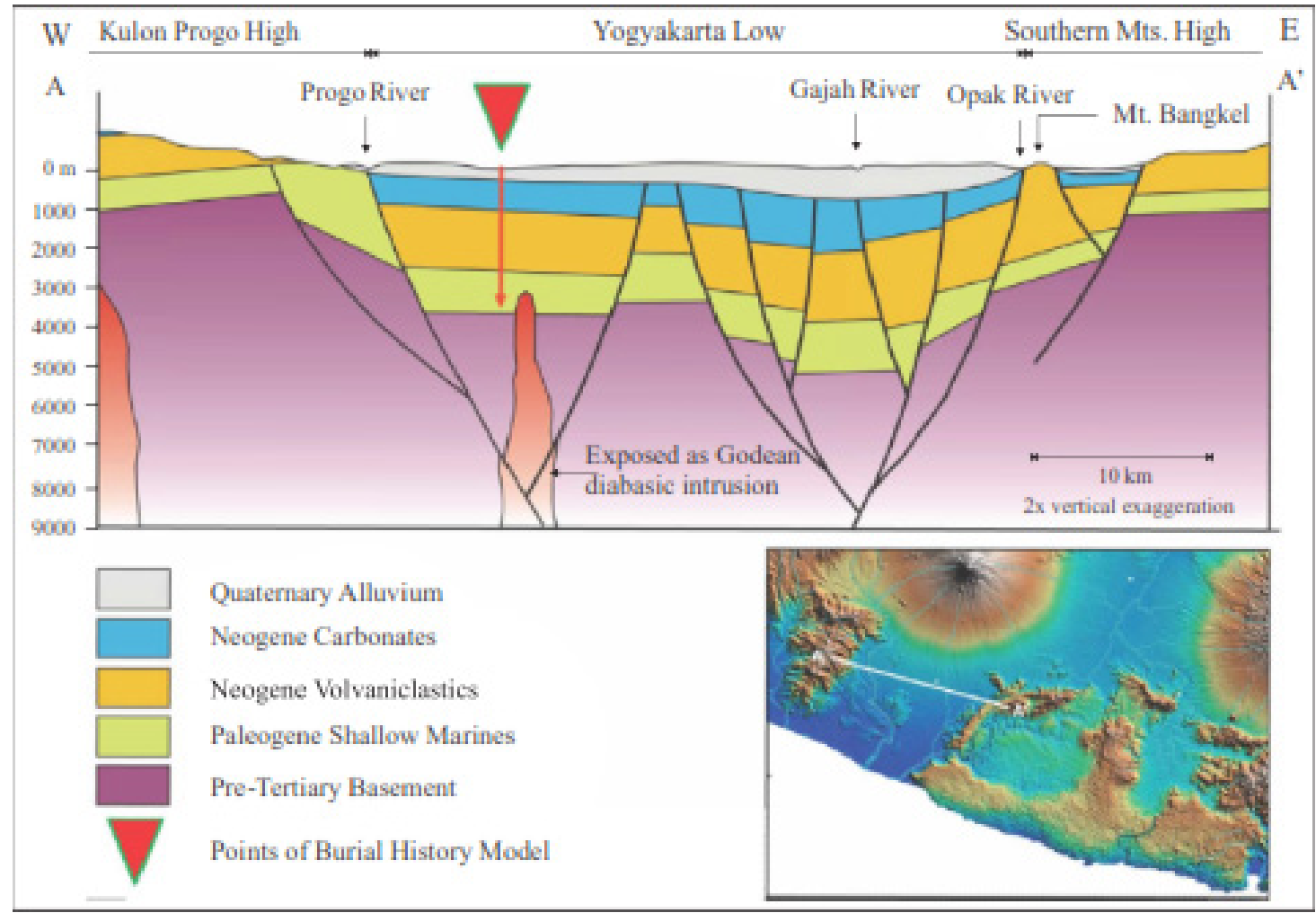

Figure 6. Deposition Stratified Model as the Result of Subsurface Interpretation Based on Gravity Data (Pertamina, 2008 in Winardi et al., 2013). Magmatism of Godean that Intrude the Sedimentary Layered and Pre-Tertiary

Basement that Hypothetically Interpreted as Igneous or Metamorphic Rock (Pandita et al., 2016).

The volcano genetic perspective to understand the characteristics of basin has been put forward by Bronto et al., (2006) and the model can be applied in relation with the assessment of the relation and distribution of rocks formations in basin. It can used to estimate the sedimentation between two hills or more, with the basin as the result of eruption that is associated with caldera in the study area.

\section{Conclusions}

The volcanic landscape or geomorphology of Godean hills is associated with the features of a caldera. Volcanic rocks covering the land surface of Godean are constituted of andesite and dacite. In addition, the central part of Godean caldera is represented by G. Wungkal that is a circular crater approximately $6000 \mathrm{~m}$ in diameter.

\section{Acknowledgment}

The author would like thank to STTNAS management for research funds and other committees who have helped the research and the publication of this paper. 


\section{References}

Bronto, S. (1999) Petrologi dan Bahan Galian Industri di Daerah Godean Yogyakarta. Departemen Pendidikan dan Kebudayaan, Kantor Koordinasi Perguruan Tinggi Swasta Wilayah V Yogyakarta.

Bronto, S., Budiadi, Ev., and Hartono, G.H. (2006) A New Perspective of Java Cenozoic Volcanic Arcs, Proceedings International Geosciences Conference and Exhibition, Jakarta.

Budiadi, Ev. (2008) Peranan Tektonik dalam Mengontrol Geomorfologi Daerah Pegunungan Kulon Progo, Yogyakarta, Disertasi Doktor, UNPAD, Bandung, 204 hal. (Unpublished).

Hartono, G. (2010) Peran Paleovolkanisme dalam Tataan Produk Batuan Gunung Api Tersier di Gunung Gajahmungkur, Wonogiri, Jawa Tengah, Disertasi, UNPAD, Bandung, 335 h. (Unpublished).

Hartono, H.G. and Pambudi, S. (2015) Gunung Api Purba Mujil, Kulonprogo, Yogyakarta: Suatu Bukti dan Pemikiran, Prosiding ReTII ke 10, STTNAS Yogyakarta.

Lelono, E.B. (2000) Palynological Study of the Eocene Nanggulan Formation, Central Java, Indonesia. Unpublished PhD Thesis. Dept. of Geology, Royal Holloway Univ. of London

Marks, P. (1957) Stratigraphic lexicon of Indonesia. Republik Indonesia, Kementerian Perekonomian, Pusat Djawatan Geologi.

Pandita, H., Sukartono, S., \& Isjudarto, A. (2016) Geological Identification of Seismic Source at Opak Fault Based on Stratigraphic Sections of the Southern Mountains. Forum Geografi, Vol. 30, No. 1, pp. 77-85.

Rahardjo, W., Sukandarrumidi, and Rosidi, H.M.S. (1977) Peta Geologi Lembar Yogyakarta skala 1:100.000. Direktorat Geologi, Bandung.

Rahardjo, W. (1995) Geological map of the Jogjakarta Sheet, Jawa. 2nd edition. Geological Research and Development Centre, Bandung.

Sipatriot, R. F. (2016) Geomorfologi Gunung Api Purba Godean, Kecamatan Godean, Kabupaten Sleman, Provinsi DIY, Seminar Geologi, J. Teknik Geologi, STTNAS, Yogyakarta. (Unpublished).

Sujanto F.X. and Roskamil (1975) The Geology and hydrocarbon Aspects of the South Central Java, Prosiding Pertemuan IAGI, Bandung, Desember 1975.

Sutanto, Soeria-Atmadja, R.C. Maury, and H. Bellon (1994) Geochronology of Tertiary Volcanisme in Java, Kumpulan Makalah Seminar Geologi dan Geotektonik Pulau Jawa, Sejak Akhir Mesosoik Hingga Kuarter, Jurusan Teknik Geologi, F. Teknik UGM, Yogyakarta, p. 53-56.

Sutikno, S. (1990) The Role of Geomorphology in Physical Geography and its Application in Research. Forum Geografi, Vol. 4, No. 2.

Van Bemmelen, R. W. (1949) The Geology of Indonesia, Vol. 1A, The Hague, Martinus Nijhoff, p. 732.

Verdiansyah, O. (2016) Perubahan Unsur Geokimia Batuan Hasil Alterasi Hidrotermal di Gunung Wungkal, Godean, Yogyakarta. Kurvatek, 1(1), 9.

Winardi, S., B. Toha, M. Imron, and D. H. Amijaya (2013) The Potential of Eocene Shale of Nanggulan Formation as a Hydrocarbon Source Rock. Indonesian Journal of Geology, Vol. 8 No. 13-23. 